Document downloaded from:

http://hdl.handle.net/10251/63032

This paper must be cited as:

Montava Seguí, IJ.; García Paya, R.; Bonet Aracil, MA.; Díaz-García, P. (2010). Textile industry indicators for management. Total Quality Management and Business Excellence. 21(1):1-9. doi:10.1080/14783360903492470.

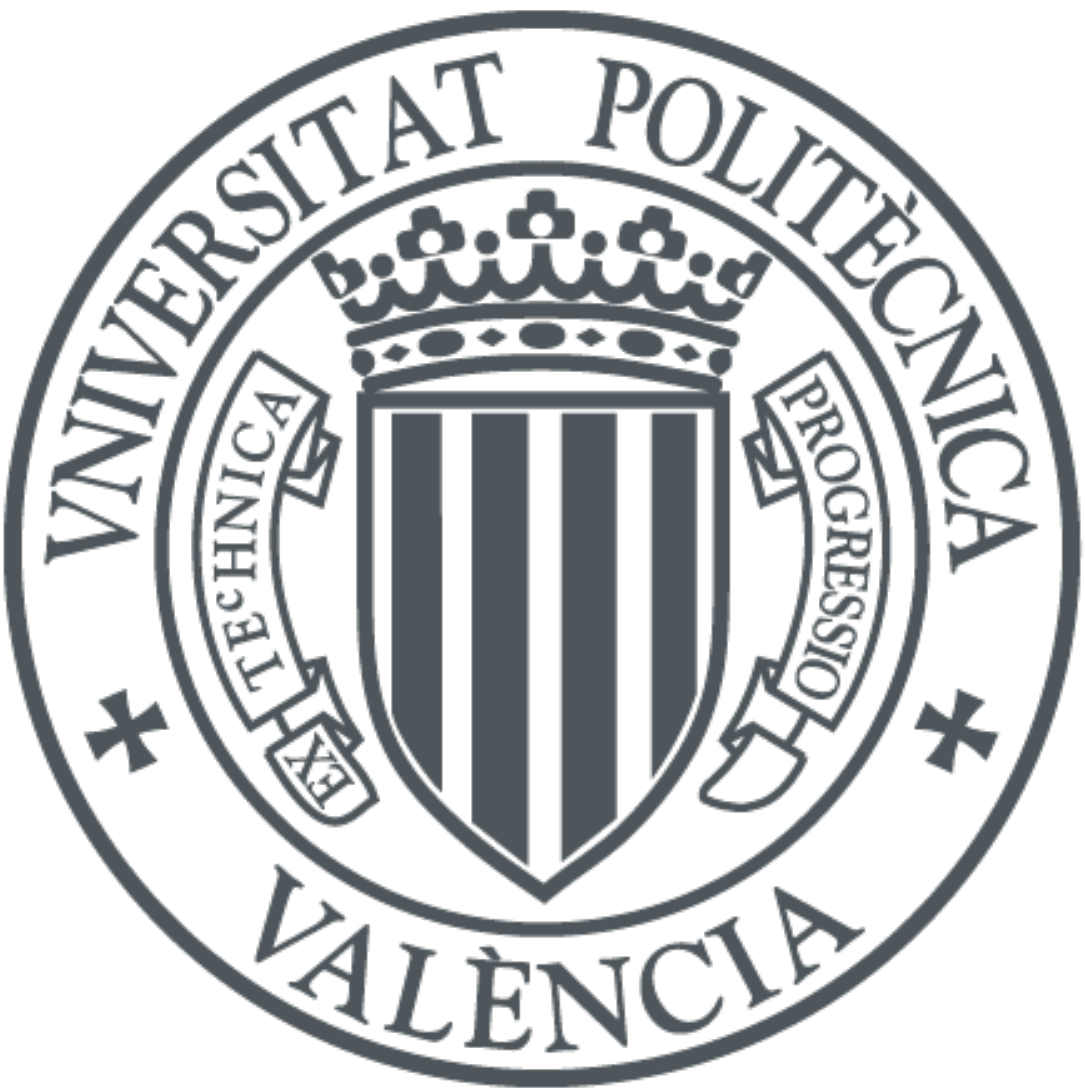

The final publication is available at

http://dx.doi.org/10.1080/14783360903492470

Copyright Taylor \& Francis (Routledge): SSH Titles

Additional Information 


\title{
TEXTILE INDUSTRY INDICATORS FOR MANAGEMENT
}

\section{Subject: Manuscript: Textile Industry Indicators for Management,}

\section{Pablo Díaz García (P.Díaz) pdiazga@txp.upv.es}

Escuela Politécnica Superior de Alcoy. Plaza Ferrandiz y Carbonell, 1. E-03801, Alcoy. Spain. Tel. +34966528470. FAX+34 966528438

2. Ma Ángeles Bonet Aracil (M.Bonet) maboar@txp.upv.es

Escuela Politécnica Superior de Alcoy. Plaza Ferrandiz y Carbonell, 1. E-03801, Alcoy. Spain. Tel. +34966528470. FAX+34 966528438

3. Ignacio Montava Seguí (I.Montava) imontava@txp.upv.es

Escuela Politécnica Superior de Alcoy. Plaza Ferrandiz y Carbonell, 1. E-03801, Alcoy. Spain. Tel. +34966528470. FAX+34 966528438

\section{Roberto García Payá (R.García)}

Escuela Politécnica Superior de Alcoy. Plaza Ferrandiz y Carbonell, 1. E-03801, Alcoy. Spain. Tel. +34966528470. FAX+34 966528438

\section{TEXTILE INDUSTRY INDICATORS FOR MANAGEMENT}

\author{
IGNACIO MONTAVA, ROBERTO GARCÍA, Ma ANGELES BONET, PABLO DÍAZ
}

\begin{abstract}
Traditional accounting is based on financial indicators, balanced scorecard divides management into different perspectives, suggesting some authors no more than four or five for each company. To measure each perspective some indicators should be defined. The aim of this work is to propose some indicators that fit each perspective for some textile companies that work in weaving fabrics. These indicators are specific for them, and very useful, when applied it will help on companies' management nowadays that globalization happened. Businesses must strive to increase their competitive advantage, which will increasingly depend on the parameters of innovation, development of new products, versatility, quality, costs, etc, and indicators will measure it.
\end{abstract}

\section{KEY WORDS}

Balanced Score Card

Indicator

Textil

Weaving

INTRODUCTION 
Traditional accounting is based on financial indicators, and several firms have adapted different management systems to performance measurement system with non financial indicators ${ }^{[1]}$. Intangibles are considered th key to understand value creation, Thus intellectual capital is the driver to future wealth creation ${ }^{[2-3]}$.

At the present time the textile and garment-making sector is fixed, along with other traditional sectors such as toy and shoe making, within a new world framework formed by the phenomena of globalisation and the influence of certain developing countries. This phenomenon will become even more pronounced in the coming years. The textile industry shares the characteristics common to other sectors of manufacturing industry, one of which is the great effect of labour costs on the price of the final product. The entry of China into the World Trade Organisation in 2001 has given even greater importance to this date, since it meant that the world's largest textile manufacturing country now had access to the European and North American consumer markets. In this environment of change, businesses must strive to increase their competitive advantage, which will increasingly depend on the parameters of innovation, development of new products, versatility, quality, costs, etc. ${ }^{[4]}$

Business companies will therefore need management systems that supply them with up-to-the-minute information on all relevant parameters and managers will need constant information both on the individual situation of each company and of the general state of the rapidly changing situation.

\section{ANALYSIS}

After a bibliographical analysis of the most widely used management systems, the following series of conclusions was reached:

- There is no generally accepted "bibliographical agreement" on the optimum model. In the bibliography studied, different authors defend certain models and criticise others, so that it cannot be said that any of the models is generally accepted as complete and ideal by all authors. [7-8]

- Most of the authors consulted agreed that there was a need to use information systems and business indicators that were structured according to the different methods analysed. ${ }^{[6-9]}$

- The majority of authors supported a system of management by company processes. ${ }^{[10-11]}$

- Process indicators must originate from different levels within the firm in the form of a pyramid, the base of which includes all the details necessary for each case. $[5,7,8,9]$

- Indicators form part of a cause-effect chain of values. ${ }^{[5,7,8,9]}$ 
- To achieve the firm's required objectives, the relevant company processes must be improved. This improvement will be reflected by the measures contained in the process indicators. ${ }^{[7,8,9,12]}$

- Companies with similar processes have similar control mechanisms. ${ }^{[11]}$

- The ideal number of indicators to constitute a suitable Control System for the management of a company is around $25 .{ }^{[5,6,7,10,13]}$

\section{CHARACTERISTICS REQUIRED OF THE SYSTEM OF INDICATORS}

As was concluded from the previously quoted analysis of the necessity for a system of indicators, it is clear that, in order for management to do its job, those responsible need the support of a series of data and reports, both internal and external, to which we give the name of MANAGEMENT INFORMATION. It is therefore necessary to analyse the priorities of the company, its objectives and the aspects in which the company aims to be different. The ways in which the company can reach its established objectives can then be defined.

The importance of measures can be judged from the fact that many authors quote the sentence "Only that which can be measured can be improved." In order to direct the company actions, both strategic and operational, it is necessary to have up-to-date specific information on the evolution of the company in the necessary fields as well as the consequences of the decisions on the evolution of the different fields. ${ }^{[14]}$

The indicators traditionally used by companies are financial indicators, proceeding from the company accounts, which suffer from the following disadvantages: ${ }^{[10,11,14]}$

- The information is subsequent to actions already carried out by the company during a time period which has already been registered in the company accounts.

- The data provided only indicate financial results and do not provide any information on the reasons that caused them.

- They give a general vision of the situation with no details of the decisive elements of company policy.

- They do not consider intangible aspects that cannot be measured by financial results.

The configuration of a growing competitive environment means that companies must adapt the characteristics of the information provided by the company accounts.

An indicator can therefore be defined at the present time as a measure used to quantify the efficiency and/or efficacy of an activity or process and a System of Indicators as a set of related indicators. ${ }^{[12,15]}$

\section{CLASSIFICATION OF INDICATORS}


There exist different methods of classifying business indicators. The most significant classifications are considered to be the following:

- According to their utilisation, in Strategic Indicators and Operational Indicators. ${ }^{[16]}$

- According to the perspectives they include; one of the most outstanding, Kaplan and Norton's classification, is based on four perspectives: financial, customer-market, internal processes and innovation and growth. They also divide them into diagnostic indicators - those that maintain control as long as the company is being controlled and give warnings when unusual events happen that need immediate attention and strategic indicators - those that define a strategy designed to obtain competitive excellence. ${ }^{[7,17,18,19,20]}$

The aim of this study is to develop the optimum system of management indicators for small and medium textile businesses, one that supports the daily decision making process of the companies in the sector. It is proposed to create a source of information based on a system of indicators for management support. The system will not be based solely on financial indicators, which only provide information on past events, as has been the custom up to now. New parameters will be included to consider the evolution of the company as to how it can satisfy its own needs in order to achieve differentiation and a competitive advantage, and will also provide information on the changing business environment.

This system of indicators will need to give additional support to companies that already use their own management systems. It will therefore have to be structured according to the Excellence Model of the European Foundation for Quality Management (EFQM) and will also help businesses in their progress towards the new ISO 9000:2000. ${ }^{7,20,21]}$

The new system of indicators must be of help to companies in the new changing environment in which we are at present immersed, with a special focus on the textile sector, supporting strategic changes, flexibility, innovation, business creativity, and supply the company with complete information on the effects of previously taken strategic decisions.

Even though when the system of indicators has been created it is possible that its practical application to individual firms will involve minor adaptations, the basic system may be common to all companies of similar characteristics. Alberto $\mathrm{M}$. Ballvé in his book "Cuadro de Mando" (Business Control") states: companies of the same sector with similar size and type of customer can have similar controls. [11]

To obtain the proposed objectives, the following methodology is carried out:

a) PREPARATION: in which textile sub-sectors, selected for their importance in the environment of the pre-weaving section (household textiles), will be described and analysed. When they have been defined, 
a selection of appropriate indicators will be established for these sectors and will subsequently be ratified by experts from the sector.

b) SURVEY: including the compilation of the survey and questioning of representative companies of the different sub-sectors to be analysed, with the aim of determining the current systems used and the optimum needs for information for each of the companies.

c) RESULTS: Analysis of the survey data and selection of indicators. Construction of the indicator architecture appropriate to each sub-sector. A Serie of indicators is proposed for the management of each type of company analysed.

\section{RESULTS.}

Possible indicators are selected for consideration, sub-divided into five different perspectives: Economic, Commercial, Production Systems, Human Resources and Innovation.

The total number of business enterprises suitable for the application of this tool is calculated, from which the active participation of 30 of these companies is obtained, making up $25 \%$ of the companies in the sector. After analysing the participation of the companies, it is concluded that those with a turnover greater than $€ 3.8 \mathrm{~m}$ in the year 2003 are capable of incorporating this management system, or at least of considering its utilisation.

After evaluating the indicators, and bearing in mind that the analysis of the results cannot be subject to strict statistical criteria, since the number of firms composing the sample is not random, an indispensable requisite for any method of statistical analysis such as, for example, the comparison of hypotheses. The participating firms are those who express a desire to collaborate in the project. The aim was to achieve the maximum number of participating companies in order to obtain reliable qualitative results, with less emphasis on the quantitative aspect.

After an analysis of the opinions of the participating companies, 27 operational indicators were selected from the 111 proposed and were as follows:

\section{Insert table 1 about here \\ Insert table 2 about here \\ Insert table 3 about here \\ Insert table 4 about here \\ Insert table 5 about here}

From an analysis of the relationship between the indicators selected as a result of the study and those which the companies indicated as being the most frequently 
used, it can be concluded that $25 \%$ of the indicators most frequently used by the companies include $63 \%$ of those selected for inclusion in the management scorecard for this type of company. It can also be concluded that the companies use a considerable number of indicators that can be considered as useful for management, but not in any precisely structured way. It is possible that they are used as elements required to determine certain information without constituting the full management aid that they can provide.

In order to carry out this work, a different procedure was used to that normally used when carried out in an individual company. The firm begins by clearly defining its critical success factors or objectives, and then defines the appropriate factors. The company thus focuses on certain basic indicators related to its most important objectives. In this case, it is decided to use the option of determining the indicators utilised or those considered important so as to be able to extract from them those considered to be the critical success factors.

An analysis of the results obtained thus gives the critical success factors divided into the five proposed perspectives and also provides a definition of a strategic map (see figure 1), as indicated below, in which it can be appreciated how the selected indicators will fit into the strategy to be followed by the company in order to reach its required financial objectives.

\section{Insert figure 1 about here}

\section{CONCLUSIONS.}

After analysing the results obtained by the study the critical success factors of the identical firms involved in the pre-weaving sub-sector in Valencia could be deduced from the selection of measurements that the firms themselves consider important for efficient business management. By controlling the selected values the companies can evaluate strategic decisions.

A management system is proposed based on a Management Scorecard composed of 27 indicators, with which it is intended that business managers can quickly obtain an overall view of the operations of the company and its most important parameters. With these indicators the situation of the company can be diagnosed at all times and the elements that have contributed to this situation can be determined.

The scoreboard proposed for the typical business firm involved in this study is considered suitable for all companies, although it can also be adapted to the specific requirements of individual firms in the sub-sector. All will have a basically common content, as can be seen from the results obtained.

As has been observed, the financial indicators are at this time still considered to be the most important business indicators. In this study they have been reduced to four ratios, representing approximately $15 \%$ of the business indicators included in the Management Scorecard. The results obtained are therefore considered to be 
innovative in that a business management is proposed in which financial results are only considered to be the result or consequence of the management policies applied to the company and a measure of the other critical success factors involved in the organisation.

The indicators most highly valued coincide with those most frequently used by the firms. This fact leads one to suppose that the business enterprises are mostly aware of their Critical Success Factors but do not use them in a structured system that guarantees business success. It is possible that they are used as elements required to determine certain information without constituting the full management aid that they can provide.

In the section referring to the interrelationships between indicators, the great importance given to personnel training in modern companies can be observed. Having adequately trained staff means that the company can improve all its critical success factors.

The result of applying an appropriate system of indicators that measures the company's critical success factors also implies that it can easily establish a system of incentives appropriate to its specific needs.

After the firms involved in the study had accepted the system, in this case firms involved in the production of household textiles, it is proposed to apply this line of study to other sub-sectors within the textile industry, such as, for example, spinning, dyeing, finishing and garment making. In fact, some firms in these sectors have already inquired about the possibility of investigations being carried out in their areas.

\section{ACKNOWLEDGEMENTS}

The authors wish to thank the Language Support Department of the Polytechnic University of Valencia for their help in translating this paper.

\section{REFERENCES}

Bulk, PN, Johansen, MR. Mouritsen, (2002) Journal Singapore

Management Review.vol 24 Issue 3, pp. 21-23

2 Stewart, T.A., (1997). Intellectual capital. Nicolas Brealey Publishing: London.

Edvinsson, L. \& Malone, MS., (1997). Intellectual Capital. Pitakus. London

Pere Lleonart, Àlvar Garola.(2003) El impacto de la liberización de los intercambios comerciales en el sector textil confección. (Gabinet

4 D'estudis Econòmics S.A. Josep $M^{\mathrm{a}}$ Arús, Estudis Econòmics I Serveis Empresarials. Minesterio de Ciencia y Tecnología )

Alfonso López Viñegla. (2003) Gestión Estratégica y Medición. El

5 cuadro de mando como complemento del Balanced Scorecard. Ed. Asociación Española para la Calidad.

6 Alberto Fernandez (2001). El Balanced Scorecard. Ayudando a 
implantar la estrategia. IESE. (3)

Robert S. Kaplan y David P. Norton. (1996) The Balanced Scorecard:

Translating strategy into action. (by The president and fellows of Harvard College. Harvard Business School Press)

Pierre Baffert, Pilles Frachon. (1989) Tableau de bord de gestion de la P.M.E. Editions du Moniteur.

A.M. Ballvé. (2001)Cuadro de mando. Organizando información para crear valor. Ed. Gestión 2000.

Amado Salgueiro.(2001) Indicadores de gestión y cuadro de mando. Ed. Díaz de Santos.

Nils-Göran Olve, Jan Roy y Magnus Wetter. (1999) Perfomance

11 Drivers. A practical Guide to Using the Balanced Scorecard. (Ed Joh Wiley \& Sons, N. Cork.

12 Miguel Angel Heras. (2001) (Sistema de Indicadores para la

Excelencia Empresarial Conference). Ed. ESADE .

Robert S. Kaplan, David P. Norton (1996). Using the Balanced

Scorecard as a Strategic Management Systems.

Harvard Business Review (76)

José Antonio Heredia Álvaro. (2001) Sistema de indicadores para la

14 mejora y el control integrado de la calidad de los procesos. Ed.

Publicacions de la Universitat Jaume I.

Joaquin Membrado. (2003) Una metodología para la mejora. (Escuela

15 Politécnica Superior de Alcoy y Asociación Española para la Calidad. Conference )

J. Curry, A. Curry. (2000) The customer Marketing Method.(Customer Relationship Management). Ed. The Customer Marketing Institute BV. AENOR. Transición de la norma UNE-EN-ISO 9001/2/3:1994 a la Norma UNE-EN-ISO 9001:2000. Consejos prácticos sobre el despliegue de objetivos y los indicadores. Asociación Española de Normalización.

Robert S. Kaplan. David P. Norton (2001) The strategis Focused Organization. Harvard Business School Publishing Corporation. Robert M Grant.(2001) Contemporany strategis analysis: concepts, techniques, applications Ed. Blackwell Publishers a publishing imprint of Basil Blacwell Inc. 238 Main Street. Cambridge, Massachusetts. 02141 USA Asociación Española para la Calidad (1998) Contabilidad de gestión. 17 indicadores para la gestión empresarial. Ed. AECA.

21 Joaquín Membrado Martinez.(1999) La gestión empresarial a través del modelo europeo de excelencia de la E.F.Q.M. Ed Diaz de Santos. 
FIGURE CAPTIONS

Figure 1.- Strategic map. 


\section{FIGURE}

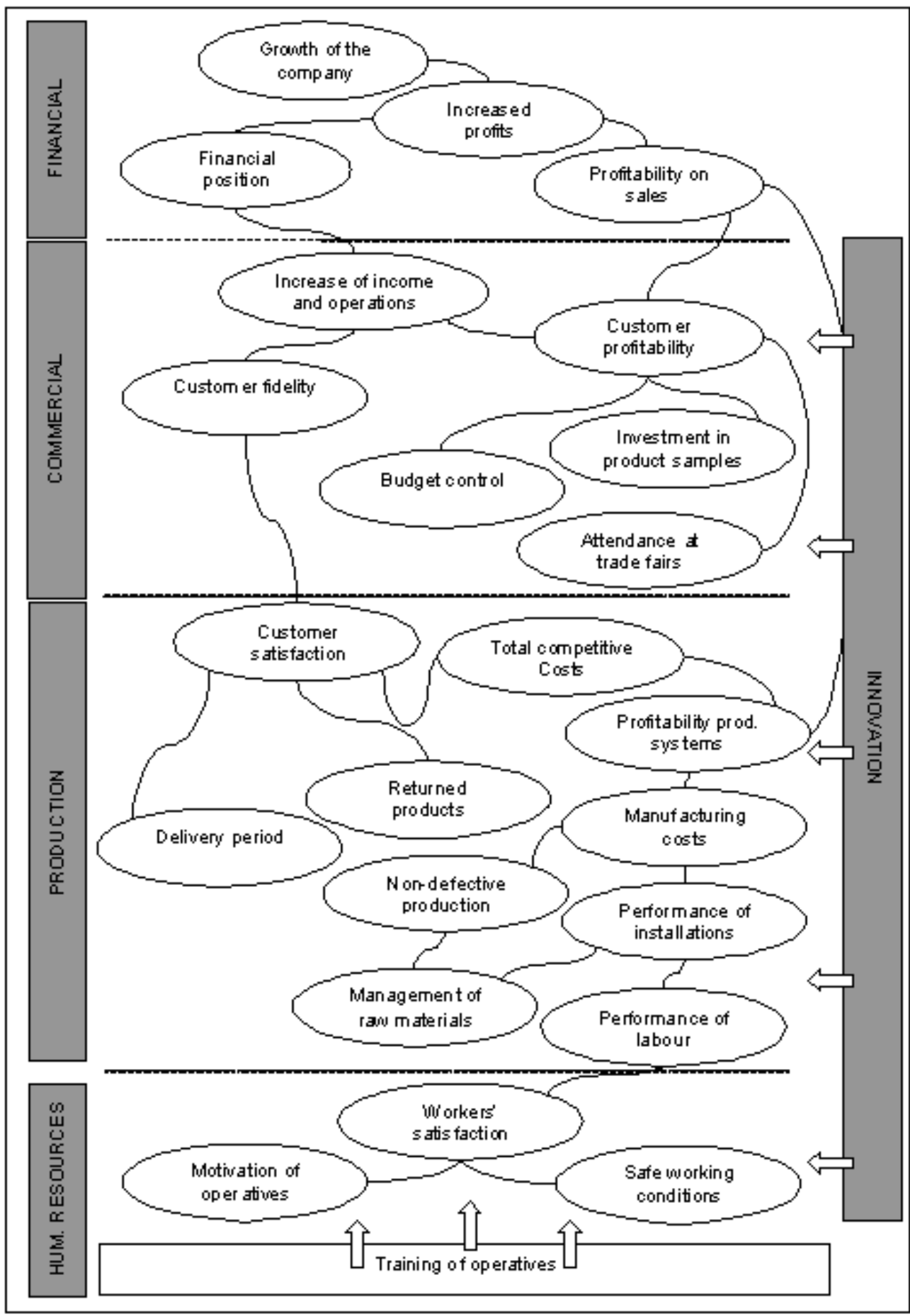




\section{TABLES}

Table 1.- FINANCIAL INDICATORS

\begin{tabular}{|c|c|c|}
\hline 1 & LIQUIDITY & $\begin{array}{l}\text { Comparison of total Current Assets and total } \\
\text { Current Liabilities. }\end{array}$ \\
\hline & $\frac{\text { Current assets }}{\text { Short term Liabilities }}$ \\
\hline
\end{tabular}

\begin{tabular}{|l|c|c|}
\hline 2 & $\begin{array}{c}\text { COEFFICIENT OF } \\
\text { SOLVENCY }\end{array}$ & Analyses the company debts. \\
\hline & $\frac{\text { Share capital }}{\text { Debt Capital }}$ \\
\hline
\end{tabular}

\begin{tabular}{|c|c|c|}
\hline 3 & PROFITS ON SALES & $\begin{array}{l}\text { Gives Net Profits, after interest and taxes, } \\
\text { as a percentage of Turnover. }\end{array}$ \\
\hline & $\frac{\text { Net Profits }}{\text { Turnover }}$ \\
\hline
\end{tabular}

\begin{tabular}{|c|c|l|}
\hline 4 & \multicolumn{1}{|c|}{ EVA } & $\begin{array}{l}\text { Difference between Operative Profit (before } \\
\text { Interest, after Tax) and the results that } \\
\text { (ECONOMIC VALUE ADDED) } \\
\text { current interest rates }\end{array}$ \\
\hline & $\begin{array}{l}\text { EVA=NOPAT - legal interest } \times \text { Captital } \\
{ }^{*}\end{array}$ \\
$\begin{array}{l}\text { NOPAT = Net Operating Profit after Tax. } \\
\text { LEGAL INTEREST = Interest Rate according to current } \\
\text { legislation (e. g. According to Law 61/03 in 2004 = } \\
3.75 \%) \\
\text { Capital = Capital Employed }\end{array}$ \\
\hline
\end{tabular}


Table 2.- PRODUCTIVE INDICATORS

\begin{tabular}{|c|c|l|}
\hline PERCENTAGE OF & $\begin{array}{l}\text { Gives units of defective products as } \\
\text { percentage of total production. } \\
\text { MEFECTIVE PRODUCTS }\end{array}$ & $\begin{array}{l}\text { Must be considered an absolute value of } \\
\text { production or in reference to the processes } \\
\text { that caused the defects. }\end{array}$ \\
\hline & $\left.\frac{\text { Defective Units }}{\text { Total Production }}{ }^{*}\right]$ \\
\hline
\end{tabular}

\begin{tabular}{|c|c|c|}
\hline 6 & $\begin{array}{c}\text { DEFECTIVE GOODS } \\
\text { RETURNED BY CLIENTS }\end{array}$ & $\begin{array}{l}\text { Goods returned by final customers due to } \\
\text { product defects. }\end{array}$ \\
\hline & $\frac{\text { Units returned }}{\text { Units delivered }}[*]$ \\
\hline
\end{tabular}

\begin{tabular}{|r|c|l|}
\hline 7 & PROCESS COST & $\begin{array}{l}\text { Cost of value added in each production } \\
\text { process. }\end{array}$ \\
\hline & $\begin{array}{r}\text { Process cost }= \\
=\frac{\text { monthly section cost }}{\text { metres of weft inserted }}\end{array}$ \\
\hline
\end{tabular}

\begin{tabular}{|c|c|c|}
\hline 8 & PRODUCTION COST & $\begin{array}{l}\text { Incidence of production costs on turnover } \\
\text { and on total costs. }\end{array}$ \\
\hline & $\frac{\text { Total production cost }}{\text { Turnover }}$ \\
\hline
\end{tabular}

\begin{tabular}{|c|c|c|}
\hline 9 & $\begin{array}{c}\text { COST OF RAW } \\
\text { MATERIALS }\end{array}$ & $\begin{array}{l}\text { Indicates the ratio between the production } \\
\text { process cost and the cost of the raw } \\
\text { materials employed. }\end{array}$ \\
\hline & $\%$ material = material/total cost of unit [*] \\
\hline
\end{tabular}

\begin{tabular}{|c|c|l|}
\hline 10 & $\begin{array}{c}\text { TOTAL INSTALLATION } \\
\text { PERFORMANCE }\end{array}$ & $\begin{array}{l}\text { Considering pre-weaving to be the } \\
\text { fundamental section, the performance of the } \\
\text { fundamental section will be taken as the } \\
\text { installation performance. }\end{array}$ \\
\hline & $\begin{array}{c}\text { P\% section }= \\
=\frac{\text { metres of weft inserted }}{\text { Theoretical metres inserted }}\end{array}$ \\
\hline
\end{tabular}

\begin{tabular}{|c|c|l|}
\hline 11 & OPERATIVES & $\begin{array}{l}\text { Ratio between turnover and the total } \\
\text { number of employees required to produce it. }\end{array}$ \\
\hline & $\frac{\text { Total Turnover }}{\text { Operatives employed }}$ \\
\hline
\end{tabular}

\begin{tabular}{|c|c|c|c|}
\hline 12 & $\begin{array}{c}\text { LABOUR COSTS AND } \\
\text { TURNOVER }\end{array}$ & $\begin{array}{l}\text { Indicates the ratio between production } \\
\text { process costs and the labour cost involved. }\end{array}$ \\
\hline & & $\%$ Labour. = Labour Cost/Total Unit Cost $\left.{ }^{*}\right]$ \\
\hline
\end{tabular}


Table 3.- COMMERCIAL INDICATORS

\begin{tabular}{|c|c|c|}
\hline 13 & TURNOVER & Value of total (or accumulated) turnover. \\
\hline \multicolumn{3}{|c|}{ Value of Turnover } \\
\hline 14 & $\begin{array}{l}\text { NUMBER OF } \\
\text { CUSTOMERS }\end{array}$ & $\begin{array}{l}\text { Total of customers involved in commercial } \\
\text { relations with the company. }\end{array}$ \\
\hline & & \multicolumn{1}{|c|}{ Total Customers. } \\
\hline
\end{tabular}

\begin{tabular}{|l|l|l|l|}
\hline 15 & CUSTOMER FIDELITY & $\begin{array}{l}\text { Ratio of regular customers to total } \\
\text { customers. }\end{array}$ \\
\hline \multicolumn{3}{|c|}{$\frac{\text { Regular customers }}{\text { Total customers }}$} \\
\hline
\end{tabular}

\begin{tabular}{|l|c|l|}
\hline 16 & DELIVERY PERIOD & $\begin{array}{l}\text { Time elapsed between date of order and } \\
\text { date of delivery. }\end{array}$ \\
\hline & $\frac{\left.\sum_{\text {orders }} \text { (Despatch date - Order date }\right)}{\text { Total orders }}$ \\
\hline
\end{tabular}

\begin{tabular}{|c|c|c|}
\hline 17 & BAD DEBTS & Ratio of bad debts to total turnover. \\
\hline & $\frac{\text { Bad debts }}{\text { Turnover }}$ \\
\hline
\end{tabular}

\begin{tabular}{|c|c|c|}
\hline 18 & SAMPLES & $\begin{array}{l}\text { Ratio between cost of producing samples } \\
\text { and total turnover. }\end{array}$ \\
\hline & $\frac{\text { Cost of samples }}{\text { Turnover }}$ \\
\hline
\end{tabular}

\begin{tabular}{|c|c|c|}
\hline 19 & $\begin{array}{c}\text { ATTENDANCE AT } \\
\text { TRADE FAIRS }\end{array}$ & $\begin{array}{l}\text { Ratio between cost of attending fairs and } \\
\text { turnover. }\end{array}$ \\
\hline & & $\frac{\text { Cost of attending fairs }}{\text { Turnover }}$ \\
\hline
\end{tabular}


Table 4.- HUMAN RESOURCE INDICATORS

\begin{tabular}{|c|c|c|}
\hline 20 & WORK ACCIDENTS & Personnel accident rate at work. \\
\hline & & Total accidents \\
\hline
\end{tabular}

\begin{tabular}{|c|c|c|}
\hline 21 & ABSENTEEISM & $\begin{array}{l}\text { Ratio between time lost and time spent at } \\
\text { work. }\end{array}$ \\
\hline & \multicolumn{1}{c}{$\frac{\text { Hours absent }}{\text { Total working hours }}$} \\
\hline
\end{tabular}

\begin{tabular}{|l|l|l|}
\hline 22 & $\begin{array}{c}\text { EMPLOYEES INVOLVED } \\
\text { IN ANNUAL } \\
\text { REFRESHER COURSES }\end{array}$ & $\begin{array}{l}\text { Number of operatives that have attended } \\
\text { refresher courses during current year in } \\
\text { order to improve their work training. }\end{array}$ \\
\hline & $\frac{\text { Operatives on refresher courses }}{\text { Total workers }}$ \\
\hline
\end{tabular}

\begin{tabular}{|c|c|c|}
\hline 23 & $\begin{array}{c}\text { OPERATIVES WITH } \\
\text { SPECIFIC } \\
\text { QUALIFICATIONS I } \\
\text { TRAINING }\end{array}$ & $\begin{array}{l}\text { Ratio of operatives with job-specific } \\
\text { qualifications to total operatives. }\end{array}$ \\
\hline & & $\frac{\text { Qualified operatives }}{\text { Total operatives }}$ \\
\hline
\end{tabular}

\begin{tabular}{|c|c|c|}
\hline 24 & WAGE COSTS & $\begin{array}{l}\text { Labour costs per hour may refer to the } \\
\text { entire company or to a specific section }\end{array}$ \\
\hline & $\frac{\text { Total wage costs }}{\text { Total working hours }}$ \\
\hline
\end{tabular}


Table 5.- INNOVATION INDICATORS

\begin{tabular}{|c|c|c|}
\hline 25 & INNOVATION EFFICACY & $\begin{array}{l}\text { Cost of innovation as a ratio of total } \\
\text { turnover. }\end{array}$ \\
\hline & $\begin{array}{c}\text { ¡Error! No se pueden crear objetos } \\
\text { modificando códigos de campo. }\end{array}$ \\
\hline
\end{tabular}

\begin{tabular}{|c|l|l|l|}
\hline 26 & INNOVATION EFFICACY & $\begin{array}{l}\text { Cost of innovation as a ratio of total } \\
\text { turnover. }\end{array}$ \\
\hline & \multicolumn{2}{|c|}{ Innovation costs } \\
\hline
\end{tabular}

\begin{tabular}{l|c|l|l}
27 & PROFITS DERIVED & Profits made by the company from new
\end{tabular} 27 FROM NEW PRODUCTS products or markets.

Percentage of profits from new products over sale price. 